\title{
Lynas Corporation's Rare Earth Extraction Plant in Gebeng, Malaysia: A Case Report on the Ongoing Saga of People Power versus State-Backed Corporate Power
}

\author{
Kai-Lit Phua ${ }^{1 *}$, Saraswati S. Velu ${ }^{1}$
}

\begin{abstract}
Background: An Australian company called Lynas Corporation is building the world's largest rare earth extraction plant at Gebeng near the city of Kuantan in Malaysia. This project is very controversial in Malaysia because of fears about possible negative health, environmental and economic impacts once the plant begins operation.

Methods: Material was gathered through mass media reports, official Lynas Corporation publications and press releases, and public statements as well as personal communication with opponents of the plant.

Results: Lynas Corporation, backed by public authorities such as the government of the state of Pahang of which Kuantan is the capital city, claims that the plant is not a threat to public health; the wastes generated can be disposed of safely; and that the economic benefits will be substantial. Critics argue that the wastes produced will be in huge amounts and they will be a grave threat to health because the wastes would include radioactive thorium and uranium. Critics also claim that the methods of waste processing and disposal being proposed by Lynas Corporation are deplorable and irresponsible. Furthermore, contrary to the assertions of Lynas Corporation, the economic benefits are dubious because of the twelve year tax holiday granted by the Malaysian authorities, the low number of jobs that will be created, and the negative impact that the project is already exerting on property values in the Kuantan region.

Conclusions: Citizen resistance to the project is ongoing and fierce. In mid-March 2012, the project is still at an impasse. A "temporary operating license" has been granted by the Malaysian authorities but the situation remains unclear because the Lynas plant is still under construction and opponents are taking legal action in order to stop it from operating when it is finished. It remains to be seen if this relatively rare mobilization of "people power" in politically authoritarian Malaysia will be able to defeat state-backed transnational corporate power.
\end{abstract}

\section{Background}

Australia's Lynas Corporation is building the world's largest rare earth extraction plant at Gebeng near the city of Kuantan in Malaysia. The planned capacity is 22,000 tonnes per annum [1]. Kuantan is the capital of Pahang state and its metropolitan area has a population of more than half a million. It is located at the edge of the South China Sea.

This project has generated great controversy in Malaysia because of fears by its opponents that there will be major negative health, environmental and economic impacts once the plant begins operation (possibly in the second half of 2012). These fears are reinforced by the fact that an earlier rare earth plant located at Bukit Merah in the western region of Peninsular Malaysia was shut down after negative health effects on plant workers and nearby residents became apparent and environmental radioactive contamination was detected. Clean up operations continue to this day [2].

Lynas Corporation, backed by public authorities such as the government of the state of Pahang, claims that the plant is not a threat to public health because the raw material - to be shipped in from Mount Weld in Western Australia and processed in Gebeng emits very low levels of radioactivity [3]. It also claims that the wastes generated can be processed and disposed of safely; and that the economic benefits to Malaysia generated by the rare earth extraction plant will be substantial [4].

*correspondence: phuakl@hotmail.com

'School of Medicine and Health Sciences, Monash University

Sunway Campus, Jalan Lagoon Selatan, 46150 Bandar Sunway

Selangor, Malaysia.
Critics argue that the wastes produced will be in huge amounts and they will be a grave threat to health because the wastes would include radioactive material such as thorium and uranium. Harm to health depends on the "dose-response relationship" (i.e. the greater the exposure to ionizing radiation, the greater the damage to the human body) and thus exposure to unnecessary radiation should be avoided whenever possible. Critics also claim that the methods of waste processing and disposal being proposed by Lynas Corporation are unsafe and socially irresponsible.

From the scientific literature, we note that any waste exhibiting the characteristics of ignitability, corrosivity, reactivity or toxicity is considered as hazardous. Organic compounds (e.g. cyanide, paint, dye, pesticide, pharmaceutical waste) and heavy metals (e.g. mercury, arsenic, lead, chromium, thorium, uranium) are the two major types of hazardous wastes [5].

Uranium $(U)$ is a radioactive heavy metal, which may occur in different oxidation states. The most stable state is the hexavalent state, which is easily soluble in water and found as the uranyl ion $\left(\mathrm{UO}_{2}{ }^{2+}\right)$. The high toxicity of hexavalent $\mathrm{U}$ compounds is correlated to their solubility. Uranyl ion can also form complex with other anions like bicarbonate, citrate, phosphate or proteins in the biological system [6]. Uranium is known as an alpha-emitting radionuclide and may cause deoxyribonucleic acid (DNA) damage if alpha particles reach cell nuclei [7]. Among the various possible modes of Uranium intake, i.e. inhalation, ingestion and through wounds, inhalation of dust in workplaces is considered the main Uranium intake pathway. In our biological system, kidney and bone seem to be the most sensitive targets for Uranium toxicosis. 
Reports relating to children (before 5 years of age) diagnosed with brain cancer states that there is an increased risk for mothers living within 1 mile of Toxics Release Inventory facility or carcinogensreleasing facility during their pregnancy compared to mothers living more than 1 mile from these facilities $[8,9]$.

Studies of thorium workers show that inhaling thorium dust (a radioactive metal) have higher chances of developing lung or pancreatic cancer many years after being exposed [10]. Prenatal exposure to chemicals like polychlorinated biphenyl (PCB) has a negative impact on neurodevelopment of age groups ranging from infants to preteens [8].

Contrary to the assertions of Lynas Corporation, opponents of the plant argue that the economic benefits are much less than claimed because of the twelve year tax holiday granted by the Malaysian authorities, the low number of jobs (only 350, including unskilled positions) that will be created, and the negative impact that the project is already exerting on property values in the Kuantan region [11].

This article discusses the ongoing political struggle between "people power" citizen groups such as Save Malaysia, Stop Lynas (SMSL) and the Stop Lynas Coalition (SLC) on the one hand and the transnational Lynas Corporation on the other hand. SMSL and SLC are assisted by the Member of Parliament for Kuantan Yang Berhormat (Right Honorable) Fuziah Salleh from the opposition political party called Parti Keadilan Rakyat or People's Justice Party while Lynas Corporation has the outright support of the Chief Minister of Pahang and the Pahang state government. Construction of the plant is ongoing. Thus, even though a very controversial "temporary operating license" was granted by the Malaysian authorities on February 1, the Lynas plant has not begun operations as of midMarch 2012.

\section{Methods}

Material for this article was gathered right from the beginning of the controversy, i.e. when the New York Times published a report on the construction of the world's largest rare earth extraction plant in Gebeng, Malaysia. Mass media reports - especially online, independent Malaysian newspapers - were carefully monitored for news on the Lynas project and the growing opposition to it by local residents and their supporters. Lynas Corporation appeared to be worried about this resistance and its Chief Executive Officer Nicholas Curtis regularly responded to critics of the project. Thus, official Lynas publications, press releases and public statements by personalities such as Curtis were also followed.

One of the most important and vocal critics of the project is Yang Berhormat Fuziah Salleh, MP for Kuantan. Thus, her public statements were also closely monitored. In addition, I engaged in personal communication (via e-mail) with her to clarify certain issues. The organization called Save Malaysia, Stop Lynas (SMSL) is the best organized of the various groups opposing the Lynas plant. They have set up an informative website. This website was regularly assessed in order to keep track of the various anti-Lynas activities organized by SMSL.

It should be noted that Malaysia has an authoritarian political system with restricted press freedom. Malaysian mainstream mass media such as the newspapers and radio and television stations are mostly owned or linked strongly to the political parties that make up the ruling coalition (BN, the Barisan Nasional or National Front) and they usually uncritically echo the views of the government. Thus, the online, independent newspapers (especially Malaysia Kini, Malaysian Insider and Free Malaysia Today) were regularly accessed for news reports on the Lynas controversy. Comments posted by readers on these websites, both pro-Lynas and anti-Lynas, were also read and taken into consideration as part of the research for this article.

The scientific literature on the wastes resulting from rare earth extraction and their possible negative effects on human health were searched using PubMed and Science Direct.

\section{Results}

Lynas Corporation claims that, unlike the earlier Mitsubishi rare earth extraction plant located at Bukit Merah, its Gebeng plant (called LAMP or the Lynas Advanced Materials Plant) is not a threat to public health because its raw material (lanthanide concentrate) emits very low levels of radiation.

The company also claims that the wastes generated can be processed into synthetic gypsum for the manufacture of plaster board; gypsum for the manufacture of cement; $\mathrm{Mg}$ rich gypsum fertilizer for plantations, crops and for soil remediation; and carbonenriched Mg gypsum fertilizer to be used to rejuvenate acidic soils [12]. The company alleges that any material remaining after processing can either be "disposed safely in a secure municipal landfill" if they are classified as non-scheduled wastes or "disposed at a licensed facility" if classified as scheduled wastes by the Department of the Environment or DOE [12].

Lynas attempts to promote the view that the plant would be beneficial to the Malaysian economy as it would be dealing with rare earths - essential elements used in high technology manufacturing and also in "green" technology such as wind turbines used to generate electricity.

Fierce critics of LAMP such as Fuziah Salleh, SMSL, SLC and SM Mohamed Idris (president of the Consumers Association of Penang and Sahabat Alam Malaysia i.e. Friends of the Earth Malaysia) are not convinced by the arguments of Lynas Corporation and its supporters. The critics point out that after rare earth extraction, the supposedly "low level radioactive" wastes (as claimed by Lynas) - from flue gas desulfurization (FGD), neutralization underflow (NUF) and water leach purification (WLP) - will nevertheless be produced in huge amounts because of the size of the plant. These will contain a lot of radioactive thorium and uranium and thus be a grave threat to the health of the public if they are not disposed of safely $[12,13]$.

Critics also claim that the methods of waste processing and disposal being proposed by Lynas Corporation are deplorable and irresponsible. Plaster board, cement and fertilizer that contain radioactive material will not only be rejected by knowledgeable consumers but may also subject people to unnecessary radiation. Above all, skeptics are highly critical of the fact that Lynas still has not come up with a long term radioactive waste management plan. Such a plan was one of the major recommendations made by a team of consultants sent to Malaysia - as the controversy grew and the Malaysian government tried to placate apprehensive members of the public - by the International Atomic Energy Agency or IAEA [14]

Opponents of the project also point out that the plant is located very near the Balok River which drains into the nearby South China Sea. This, coupled with the water table being near the soil surface, 
and the fact that the area is susceptible to flooding during the seasonal monsoon rains, means that radioactive wastes as well as the strong chemicals used in the extraction of rare earths from the raw material could easily enter nearby waters [15]. This would seriously impact the fishing industry and beach tourist industry that form a vital part of the local Kuantan area economy.

Furthermore, contrary to the assertions of Lynas Corporation, project opponents believe the economic benefits are dubious because of the twelve year tax holiday granted by the Ministry of International Trade and Industry (MITI), the low number of jobs that will be created, and the negative impact that the project is already exerting on property values in the Kuantan region. Because of all these factors, citizen resistance to the project remains ongoing and fierce.

As of mid-March 2012, the situation remains in flux. Lynas Corporation has been granted a very controversial "temporary operating license" or TOL. The granting of a TOL means that the plant can operate - at less than full capacity and for only a limited number of years. Plant operations are also subjected to certain terms and conditions and close monitoring by the Malaysian authorities. The granting of the TOL is especially controversial and has further inflamed public opinion because previous Lynas applications for an operating license had been rejected by the AELB due to the lack of a satisfactory long term radioactive waste management plan that includes provision for a "permanent disposal facility" [16]. Opponents of the plant are taking legal action in order to prevent the plant from operating once construction is finished.

The following is a chronology of major events related to the controversy [17]:

\section{March 8, 2011}

The New York Times publishes a report on the construction of the Lynas rare earth extraction plant at Gebeng. Fuziah Salleh's opposition to the plant is boosted (she had opposed the plant right from the beginning but lack of media attention meant that her opposition - by raising the issue in the Parliament of Malaysia - was initially futile)

\section{March 30, 2011}

The recently formed citizen action group Save Malaysia, Stop Lynas (SMSL) organizes a protest at the Parliament of Malaysia.

\section{April 17, 2011}

Major figures involved in the earlier protests against the Bukit Merah plant are invited and give public presentations to warn against the dangers of wastes produced by rare earth extraction.

\section{May 20, 2011}

A protest is carried out at the Australian High Commission (Embassy) in Kuala Lumpur.

\section{May 30-31, 2011}

A team from IAEA (invited by the Malaysian public authorities) visits Kuantan and anti-Lynas citizen activists make presentations to the team. Counter-demonstrators appear, make verbal threats and behave aggressively toward the anti-Lynas activists.

\section{June 26, 2011}

In the morning of June 26,4000 people take part in a protest walk against LAMP. In the afternoon, a convention of non-governmental organizations is held at a local hotel to express solidarity with the anti-Lynas movement.

\section{June 30, 2011}

The New York Times publishes another report on the Lynas plant. This creates a major "buzz" and further strengthens opposition to LAMP especially since the news report includes allegations of shoddy construction.

\section{July 3-9, 2011}

Anti-Lynas activists visit Australia and protest at the headquarters of Lynas Corporation in Sydney. They also establish ties with Australian supporters such as environmental groups.

\section{September 2-10, 2011}

Anti-Lynas activists make a second trip to Australia (this time to Western Australia where the source of the raw material is located at Mount Weld).

\section{October 9, 2011}

A Himpunan Hijau (Green Gathering) is held and attracts 5,000 participants from all over Malaysia

\section{November 13, 2011}

An innovative "whack a piñata" event is successfully organized by the anti-Lynas activists

\section{January 2012}

Lynas Corporation applies for a "temporary operating license". Its supporting documents are put on public display by the Malaysian authorities. However, the authorities are heavily criticized for restricting access to the documents e.g. access is only available in hardcopy form (not available for sale) at a limited number of sites, viewers are given only one hour to read the highly technical documents, no photography is allowed etc. Anti-Lynas activists ingeniously get around these restrictions by operating in teams to copy all the documents by hand (!). Anti-Lynas activists subsequently submit formal objections to the Lynas project with the public authorities.

\section{February 1, 2012}

The Malaysian government authorities grant Lynas a TOL. This is very controversial because the latest documents submitted by Lynas still did not include a satisfactory long term radioactive waste management plan that includes provision for a "permanent disposal facility". (It should be noted that previous Lynas applications for a full operating license were rejected precisely for this reason).

\section{Discussion \& Conclusions}

The ongoing Lynas controversy is of major significance because it involves the construction and planned operation of the world's largest rare earth extraction plant. If the plant is shoddily built and the enormous amounts of wastes that are produced are not disposed of properly, chances are an environmental disaster similar to that of Baitou in China will appear [18]. 
The fears of critics are reinforced by the fact that although the raw material will be mined at Mount Weld in Western Australia and then exported to Malaysia for processing, Western Australian authorities themselves have refused to entertain the idea of allowing any wastes generated to be shipped back to Western Australia for storage and disposal.

The capacity of the Lynas plant is ten times the size of the earlier rare earth plant that was built in Bukit Merah and subsequently shut down because of public health and environmental concerns. Thus, the volume of hazardous and radioactive wastes (containing thorium and uranium) that will be produced will be correspondingly higher. Furthermore, the fact that the Lynas plant is sited in an area susceptible to flooding - the construction site actually flooded during the late year annual monsoon season of 2011-2012 - and its proximity to Balok River and the South China Sea does little to alleviate the fears of residents of the Kuantan metropolitan area.

Mainland Chinese sources have been quoted as saying that "Every ton of rare earth produced generates approximately 8.5 kilograms ( $18.7 \mathrm{lbs}$ of) of fluorine and 13 kilograms ( $28.7 \mathrm{lbs}$ ) of dust; and using concentrated sulfuric acid high temperature calcination techniques to produce approximately one ton of calcined rare earth ore generates 9,600 to 12,000 cubic meters ... of waste gas containing dust concentrate, hydrofluoric acid, wastewater plus one ton of radioactive waste residue (containing water)". Furthermore, Wang Caifeng, the Deputy-Director of the Materials Department of the Ministry of Industry and Information Technology actually mentioned that 2,000 tons of mine tailings (which contain radioactive material such as thorium) is created for every ton of rare earth elements extracted! [19].

The anti-Lynas movement is significant in Malaysia because the country has a repressive ruling regime that has a history of using the police to physically break up peaceful demonstrations.

Furthermore, the earlier protests and demonstrations against the much smaller rare earth plant in Bukit Merah resulted in the arrest under the feared Internal Security Act (ISA) of its leading activists. The ISA allowed the regime to arrest Malaysian political dissidents using the vague charge of a "threat against national security" and also allowed indefinite detention of those arrested (since the two year jail term can be extended indefinitely by the Minister of Home Affairs).

To be fair however, anti-Lynas demonstrations - although hindered by police action such as attempts to restrict access to gathering spots for anti-Lynas demonstrators - have so far not been subjected to violence or arbitrary arrest on the part of the police.

In terms of its economic impact, opponents of the Lynas plant argue that the costs will be much greater than the benefits because of likely negative impact on the fisheries industry and the beach tourism industry of the Kuantan region. It should also be remembered that both of these industries are relatively labour intensive and employ many area residents. The small number of jobs that the Lynas project will create (only 350 according to Lynas itself) coupled with the 12 year tax holiday granted by the authorities strengthen the criticisms on economic grounds presented by the anti-Lynas groups.

The Lynas plant has also generated a spirit of social solidarity as the residents of the Kuantan area gather together in a "people power" movement to resist state-backed corporate power. Citizen resistance to the project is ongoing and fierce. The citizens of
Kuantan are also being assisted by Kuantan-born people and others residing in other parts of Malaysia and even overseas in countries such as Australia. This is an interesting phenomenon and much of it is attributable to the efficiency of communication via modern technology such as the Internet. Attempts by pro-Lynas groups to paint the anti-Lynas movement in heavily-charged ethnic terms (such as: the anti-Lynas activists are all from the Chinese-Malaysian ethnic group) or as partisan activists using the Lynas project to launch politically-motivated attacks on the government, have been largely unsuccessful. Related attempts to paint the anti-Lynas people as ignorant Luddites or "anti-development" have also been unsuccessful. The leaders of the anti-Lynas movement are highly-educated and middle class people who are also being advised by professionals knowledgeable about the dangers of wastes produced by rare earth extraction. SMSL and SLC also have the strong support of the Malaysian Medical Association and the Pahang Bar association. More recently, a new group called Himpunan Hijau (Green Gathering) has sprung up to oppose the Lynas project.

Nevertheless, the situation appears to be at an impasse as of midMarch 2012 although Lynas has been granted its highly controversial TOL. Legal action by anti-Lynas groups may delay plant operations after construction of the plant is finished. Thus, it remains to be seen if this mobilization of non-violent "people power" [20] in Malaysia will be able to defeat state-backed transnational corporate power.

\section{List of Abbreviations}

AELB Atomic Energy Licensing Board

BN Barisan Nasional (National Front)

DOE Department of the Environment

IAEA International Atomic Energy Agency

ISA Internal Security Act

LAMP Lynas Advanced Materials Plant

MITI Ministry of International Trade and Industry

MP Member of Parliament

PKR Parti Keadilan Rakyat (People's Justice Party)

SLC Stop Lynas Coalition

SMSL Save Malaysia, Stop Lynas

TOL Temporary Operating License

\section{Competing Interests}

The first author was born in Kuantan and lived there until he was 18 years old. The first author declares that he has no competing financial interests. The co-author declares that she has no competing financial interests.

\section{Author's contribution}

This article was written largely by the first author (who works in the area of public health) in consultation on technical matters with the co-author.

\section{Acknowledgements \& Funding}

A chronology of events was made available to the authors by the staff of the Save Malaysia, Stop Lynas citizen action group. No funding was sought or used in the preparation of this article.

\section{Article history}

Received: 31-Jan-2012 Revised: 22-Mar-2012

Accepted: 02-Apr-2012 Published: 10-Apr-2012 


\section{References}

1. Lynas Corporation (2011). Annual Report 2011. Sydney, Australia: Lynas Corporation Limited.

2. Consumers Association of Penang (no date) Chronology of events in the Bukit Merah Asian Rare Earth development. | Article |

3. Lynas Corporation (no date) What are rare earths? The answers are here. | Article |

4. Malaysian Insider (2011) Letter from chairman of Lynas Corporation, Nicholas Curtis, to Fuziah Salleh. Malaysian Insider, June 22. | Article |

5. Polprasert C, Liyanage LRJ (1996) Hazardous waste generation and processing. Resources, Conservation and Recycling 16: 213-226.

6. Bosshard E, Zimmerli B, Schlatter C (1992) Uranium in the diet: risk assessment of its nephron- and radiotoxicity. Chemosphere 24: 309321.

7. Melo D, Burkart W (2011) Uranium: environmental pollution and health effects. In J Nriagu (ed.) Encyclopedia of environmental health. New York: Elsevier Science. Pp. 526-533.

8. De Rosa CT, Fay M, Keith LS, Mumtaz MM, Pohl HR, Hatcher MT, Hicks HE, Holler J, Ruiz P, Johson BL (2008) Hazardous wastes. In K Heggenhougen and SR Quah (eds). International encylopedia of public health. New York: Academic Press. Pp. 107-121.

9. Choi HS, Shim YK, Kaye WE, Ryan PB: Potential residential exposure to toxics release inventory chemicals during pregnancy and childhood brain cancer. Environ Health Perspect 2006; 114;(7.);1113-8. | Pubmed Abstract | Pubmed Full text

10. Gad SC (2005) Thorium and thorium dioxide. In B Anderson, A de Peyster, SC Gad, PJB Hakkinen, M Kamrin, B Locey, HM Mehendale, C Pope, L Shugart and P Wexler (eds.) $2^{\text {nd }}$ ed. Encyclopedia of toxicology. Volume 4. New York: Academic Press. Pp. 183-184.

11. Teoh S (2011) Rare earth refinery benefits Kuantan, says Lynas. Malaysian Insider, April 12. | Article |

12. Lynas Corporation (2011) Lynas-SHE-R-043 Radioactive Waste Management Plan Rev 4.

13. SM Mohamed Idris (2011) Lynas plant rushed ahead of radiation study. Malaysiakini, May 23. | Article |

14. IAEA (2011) IAEA concludes review mission in Malaysia. June 3. I Article I

15. Save Malaysia, Stop Lynas (2012) The open letter to Malaysia government on Lynas pre-opt license application. January 13. | Article |

16. SM Mohamed Idris (2012) Lynas: AELB not adhering to IAEA recommendations. Malaysiakini, January 12. | Article |

17. Save Malaysia, Stop Lynas (no date) Chronology (of key events). Mimeo.

18. Parry S, Douglas E (2011) In China, the true cost of Britain's clean, green wind power experiment: pollution on a disastrous scale. Mail Online, January 26. | Article |

19. Hurst C (2010) The rare earth dilemma: China's rare earth environmental and safety nightmare. Cutting Edge, November 10. | Article |

20. Schock K (2008) People Power and alternative politics. In P Burnell and V Randall (eds.) $2^{\text {nd }}$ ed. Politics in the developing world. New York: Oxford University Press. Pp. 186-207.

\section{Citation:}

Phua KL and Velu SS: Lynas Corporation's Rare Earth Extraction Plant in Gebeng, Malaysia: A Case Report on the Ongoing Saga of People Power versus State-Backed Corporate Power. journal of Environmental Engineering and Ecological Science 2012, 1:2.

http://dx.doi.org/10.7243/2050-1323-1-2 